\title{
Effects of IL-7 on sepsis: a systematic review
}

\author{
Efeitos da IL-7 na sepse: uma revisão sistemática
}

\author{
Filipe Oto Cunha de Moraes ${ }^{1}$, Guilherme Tetsuo Yokoy Numakura², \\ Larissa Tami Hokama ${ }^{3}$, Francisco Garcia Soriano ${ }^{4}$.
} Moraes FOC, Numakura GTY, Hokama LT, Soriano FC. Effects of IL-7 on sepsis: a systematic review / Efeitos da IL-7 na sepse: uma
revisão sistemática. Rev Med (São Paulo). 2021 May-June;100(3):254-68.

\begin{abstract}
Objective: The aim of this systematic review to evaluate the effects and possible therapeutic relevance of interleukin-7, a novel immunoadjuvant agent, against sepsis. Data Sources: We have searched PubMed, Scopus, LILACS and SciELO for any study which had IL-7 as intervention for sepsis. Study Selection: For each source, a single author was chosen to select all studies based on title and abstract. The remaining two authors then proceeded to read the complete text for relevance assessment. Results: Eleven sources were retrieved, consisting of six studies performed on animals, four on ex vivo human cells, and a single clinical trial. Several parameters were evaluated and reported, such as improved animal survival (3 trials; $n=264$ ); improved cell count, activation, cytokine secretion, proliferation and survival; and higher patient CD4+ and CD8+ lymphocyte count ( 1 trial; $n=27$ ). Major limitations were the heterogeneity of studies and the complexity of sepsis presentation. Data Extraction: Any data related to IL-7 intervention in septic patients was extracted. Animal and in vitro data was chosen according to outcomes in either overall survival or immune response markers. The data extraction from each study was conducted by a single author and then revised by the other two. Bias was assessed by all three authors together, without any specific methodology. Conclusions: Although IL-7 as a potential therapy option for sepsis still requires further investigation and clinical evaluation, current studies show promising results of how the interleukin could act against the disorder.
\end{abstract}

Keywords: Sepsis; Interleukin-7; IL-7.
RESUMO: Objetivo: O objetivo desta revisão sistemática é avaliar os efeitos e a possível relevância terapêutica da interleucina-7, um novo agente imunoadjuvante, contra a sepse. Fontes Dados: As bases de dados PubMed, Scopus, LILACS e SciELO foram percorridas por qualquer estudo que tivesse IL-7 como intervenção para sepse. Seleção do Estudo: Para cada fonte, um único autor foi encarregado de selecionar os estudos com base no título e resumo. Em seguida, os outros dois revisores leram o texto completo para avaliação da relevância. Resultados: Onze estudos foram selecionados, dos quais de seis estudos foram realizados em animais, quatro em células humanas ex vivo e um único ensaio clínico. Diversos parâmetros foram avaliados e reportados em cada um dos estudos, como melhor sobrevida em animais ( 3 estudos; $n=264$ ); melhor contagem, ativação, secreção de citocinas, proliferação e sobrevivência de células; e maior contagem de linfócitos CD4+e CD8+em pacientes ( 1 ensaio; $\mathrm{n}=$ 27). As principais limitações foram a heterogeneidade dos estudos, além da complexidade da apresentação da sepse. Extração de Dados: Foram selecionados todos os dados relacionados ao uso intervencionista da IL-7 em pacientes sépticos. Dados de estudos em animais e in vitro foram selecionados conforme desfechos tanto de sobrevida geral quanto em marcadores de resposta imune. A extração de dados de cada estudo foi feita por um único autor, com posterior revisão pelos demais. A análise de viés foi feita pelos três autores em conjunto, sem metodologia específica. Conclusões: Embora a IL-7 como uma potencial opção terapêutica para sepse ainda exija maior investigação e mais ensaios clínicos, os estudos atuais mostram resultados promissores de como a interleucina pode agir contra a doença.

Palavras-chave: Sepse; Interleucina-7; IL-7.

Artigo desenvolvido na Disciplina Optativa Abordagem Prática da Escrita Científica da Revista de Medicina - DCFMUSP (2018-2019).

1. Acadêmico da Faculdade de Medicina da Universidade de São Paulo - FMUSP. ORCID: https://orcid.org/0000-0003-1251-9638. Email: filipe.oto@ fm.usp.br

2. Acadêmico da Faculdade de Medicina da Universidade de São Paulo - FMUSP. ORCID: https://orcid.org/0000-0001-6953-1641. Email: guilherme. numakura@fm.usp.br.

3. Acadêmica da Faculdade de Medicina da Universidade de São Paulo - FMUSP. ORCID: https://orcid.org/0000-0003-3221-2991. Email: larissa. tami@fm.usp.br.

4. Orientador. Professor Doutor, da Faculdade de Medicina da Universidade de São Paulo - FMUSP. ORCID: https://orcid.org/0000-0003-4898-0135. Email: gsoriano@usp.br.

Correspondece: Filipe Oto Cunha de Moraes. Av. Dr. Arnaldo, 455. Cerqueira César, São Paulo, SP. CEP: 01246-903. E-mail: filipe.oto@fm.usp.br. 


\section{INTRODUCTION}

Cepsis, according to the most recent consensus, Scan be defined as life-threatening organ dysfunction caused by a dysregulated host response to infection ${ }^{1}$. Aside from antibiotic therapy and supportive care, the disorder still has no currently approved immune treatment, even though more than over 100 therapeutic clinical trials have been conducted ${ }^{2}$. Such a challenge seems to be largely due to its complex clinical course. Sepsis is traditionally presented as an early hyper-inflammatory phase (SIRS) followed by an anti-inflammatory one (CARS), although recent research points to both phases happening simultaneously ${ }^{3,4}$.

Most of early potential therapies targeting sepsis focused on halting its pro-inflammatory, procoagulative phase, such as TNF- $\alpha$ antagonists, Toll-like receptor 4 (TLR4) antagonists, corticosteroids, antilipopolysaccharide and activated protein $\mathrm{C}^{5}$. More recently, the anti-inflammatory aspect of the disorder has received marked attention, as studies on sepsis "immunoparalysis" mount. Sepsis has been proven to have various deleterious effects on immune cells, including apoptosis, anergy and enhanced tolerance, which lead to a persistently impaired immunity and late mortality ${ }^{6}$. Thus, in an attempt to reverse such profile, several immunomodulatory, pro-inflammatory molecules are currently under research, chiefly among them IFN- $\gamma$, IL-15, GM-CSF, Anti-PD-1/PD-L and IL-77.

IL-7 is a cytokine produced by non-haematopoietic stromal cells that mediates anti-apoptotic and proliferative effects on T lymphocytes. The IL-7 receptor, composed of IL-7R $\alpha$ (also known as CD127) and the common cytokine receptor $\gamma$, signals through the activation of PI3K and the JAK-STAT pathway, the downregulation of p27 and the modulation of Bcl- $2^{8}$. Although IL-7 treatment is still not approved for any condition, CYT107, a glycosylated recombinant human version of the cytokine, has been the intervention of choice in clinical trials for HIV, bone marrow reconstitution, idiopathic lymphopenia, cancer, and hepatitis $\mathrm{C}$. These conditions, although very different from each other, all lead to common disruptions of the immune system, which could be also similar to the one caused by sepsis 9 .

The aim of this review, thus, is to systematically evaluate current literature on the effects of IL-7 in the sepsis-induced immune profile, in order to assess its potential as a novel treatment for the condition.

\section{METHODS}

We have searched for controlled trials that administered IL-7 to patients with sepsis or septic shock. Animal and ex vivo preclinical studies were included in order to explore the mechanisms, efficiency and limitations of the drug. There were no language or date restrictions, although the studies on pediatric patients were excluded.

The research was made on PubMed (1966 - present), Scopus (2004 - present), LILACS (1982 - present) and SciELO (1997 - present) databases. "IL-7", "interleukin-7" and "sepsis" were the searched terms.

For each database, one author was selected to search for studies and select them based on title and abstract, while the remaining authors read the complete article for relevance assessment. Disagreements were resolved by discussion between the three authors. The excluded articles were related to the pathophysiology of sepsis, immunodeficiency, general immunotherapy and/or reviews of new treatments, secondarily related diseases and also articles covering IL-7 and other cytokines as markers of sepsis instead of treatment options. Figure 1 depicts the flow diagram of article selection.

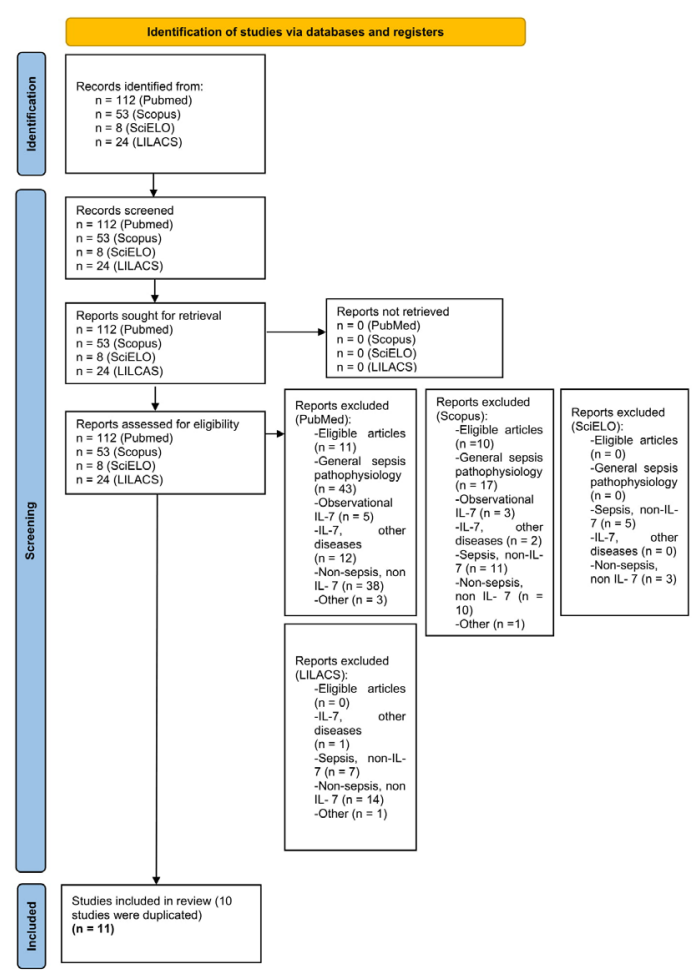

Figure 1 - Flow diagram of articles

A total of 11 articles were recovered from PubMed, 10 from Scopus and none from LILACS and SciELO. Every article selected from Scopus was also listed on PubMed. Among the final 11 studies, there were six studies performed on animals, four on ex vivo human cells, and a single clinical trial.

Data was extracted according to the following criteria. For the human study, all data related to the therapeutic use of IL-7 was extracted. For each animal and ex vivo preclinical study, a single author selected relevant 
information concerning IL-7 intervention on either (1) overall survival or (2) modified immune response markers. The remaining two authors then proceeded to review the extracted data on the selected outcomes. Data related to pre-intervention immunological markers or survival prognosis based on cellular activity, for instance, was thus excluded. Data related to the effects of IL-7 on sham animals and non septic patients were also excluded from tables, but these results could still be referenced during discussions. There was no missing or unclear information in the selected studies about population, sepsis model, intervention or outcome.

For each selected study, the elected effect measure for the result report was the mean difference between interventional and control groups. Extracted data was formatted as tables according to variables specific to each study group (animal, human ex vivo, clinical trial). For every individual study, results were synthesized and tabulated according to the categories "assessment", "sample", "intervention", "outcome" and "p-value". There was no need for data conversion to make comparison possible. No methods were employed so as to evaluate the heterogeneity among study results. Additionally, no methods were used to assess neither the robustness of the data synthesis, nor the certainty of the evidence.
Bias assessment was made by all three authors in unison. All animal studies had control groups, but no blinding. The sepsis inducing procedure and further interventions were clearly stated in every study. In vitro studies did not have blinding and control groups and were conducted on either healthy or critical (but not septic) patients' cells. The clinic trial was randomized, doubleblind and placebo-controlled. Definitions of sepsis were explicitly stated in every ex vivo and clinical trial study. After consideration, the authors came to agreement that no study was to be excluded based on possible bias risk. There were no specific methods employed to evaluate risk of bias due to missing results.

\section{RESULTS}

The retrieved studies, even after separation in either animal, human or cell-based groups, showed marked heterogeneity in regard to population, sepsis model, intervention regimen or analyzed immune function markers. Regardless, no selected study failed to fulfill the inclusion criteria. The differences between two of the groups (six animal studies and four ex vivo studies) were then summarized in Tables 1 and 2, respectively. The clinical trial, as it was the only one performed so far, was left out of the comparison.

Table 1: Animal studies

\begin{tabular}{|c|c|c|c|c|}
\hline Source & Population & Model & Intervention & Assessments \\
\hline $\begin{array}{l}\text { Unsinger } \\
\text { et al. } .^{10} \\
2010\end{array}$ & $\begin{array}{l}\text { C57BL6 } \\
\text { (inbred) } \\
\text { and CD1 } \\
\text { (outbred) } \\
\text { male mice. }\end{array}$ & $\begin{array}{l}\text { Cecal ligation } \\
\text { and puncture } \\
(\mathrm{CLP}) \text {. }\end{array}$ & $\begin{array}{l}\text { Either antibody stabilized } \\
\text { human rIL-7 (R\&D Systems) } \\
\text { and human rIL-7 (Cytheris). } \\
\text { Various regimens: } \\
-5 \mu \mathrm{g} 90 \text { min post surgery; } \\
-5 \mu \mathrm{g} \text { at } 90 \mathrm{~min}, 24 \mathrm{~h} \text { and } 48 \mathrm{~h} \\
\text { marks } \\
-5 \mu \mathrm{g} \text { for } 3 \text { consecutive days; } \\
-2.5 \mu \mathrm{g} 90 \text { min postsurgery } \\
\text { and every } 48 \mathrm{~h} \text { for two } \\
\text { additional doses. }\end{array}$ & 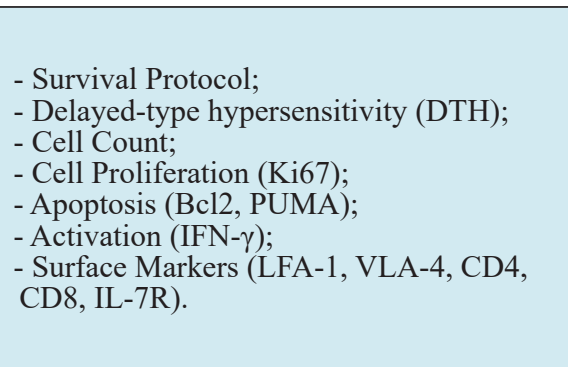 \\
\hline $\begin{array}{l}\text { Kasten et } \\
\text { al. }{ }^{11} \\
2010\end{array}$ & $\begin{array}{l}\text { C57BL/, } \\
\text { TCR } \\
\alpha \beta / \gamma \delta- \\
\text { deficient } \\
\text { and TCR } \\
\gamma \delta- \\
\text { deficient } \\
\text { mice. }\end{array}$ & $\begin{array}{l}\text { Cecal ligation } \\
\text { and puncture } \\
(\mathrm{CLP}) \text {. }\end{array}$ & $\begin{array}{l}5 \mu \mathrm{g} \text { of human rIL-7 (Cytheris) } \\
\text { post surgery. }\end{array}$ & $\begin{array}{l}\text { - Survival Protocol; } \\
\text { - Tissue Damage (AST, pulmonary MPO } \\
\text { and intestinal dry/wet ratio); } \\
\text {-bCell Count; } \\
\text { - Apoptosis (Bc12); } \\
\text { - Activation (serum IL-6); } \\
\text { - Surface Markers (CXCR3); } \\
\text { - Innate Immunity (neutrophil recruitment); } \\
\text { - Pathogen Burden (bacteremia). }\end{array}$ \\
\hline $\begin{array}{l}\text { Unsinger } \\
\text { et al. }{ }^{12} \\
2012\end{array}$ & $\begin{array}{l}\text { C57BL6 } \\
\text { (inbred) } \\
\text { or CD1 } \\
\text { (outbred) } \\
\text { male mice. }\end{array}$ & $\begin{array}{l}\text { Cecal ligation } \\
\text { and puncture } \\
\text { (CLP) followed } \\
\text { by imipenem. } \\
\text { Intravenous } C \text {. } \\
\text { albicans injection } \\
\text { followed by } \\
\text { fluconazole. }\end{array}$ & $\begin{array}{l}\text { Human IL- } 7 \text { (Cytheris). } \\
\text { Various regimens: } \\
-2.5 \mu \mathrm{g} \text { for } 5 \mathrm{~d}, 6 \mathrm{~d} \text { postsurgery } \\
\text { and } 2 \mathrm{~d} \text { after secondary } \\
\text { challenge } \\
-2.5 \mu \mathrm{g} \text { for } 4 \mathrm{~d}, 5 \mathrm{~d} \text { postsurgery } \\
\text { and } 1 \mathrm{~d} \text { after secondary } \\
\text { challenge. }\end{array}$ & $\begin{array}{l}\text { - Survival Protocol; } \\
\text { - Delayed-type hypersensitivity (DTH); } \\
\text { - Cell Proliferation (Ki67); } \\
\text { - Activation (CD69, IL-2, IFN- } \gamma, \text { TNF- } \alpha \text {, } \\
\text { and IL-6); } \\
\text { - Surface Markers (LFA-1); } \\
\text { - Pathogen Burden (Candida foci). }\end{array}$ \\
\hline
\end{tabular}


Table 1: Animal studies

\begin{tabular}{|c|c|c|c|c|}
\hline Source & Population & Model & Intervention & Assessments \\
\hline $\begin{array}{l}\text { Shindo et } \\
\text { al. }{ }^{13} \\
2015\end{array}$ & $\begin{array}{l}\text { C57BL/6 } \\
\text { mice. }\end{array}$ & $\begin{array}{l}\text { Cecal ligation } \\
\text { and puncture } \\
(\mathrm{CLP}) \text { followed } \\
\text { by imipenem. } \\
\text { Intravenous } C \text {. } \\
\text { albicans injection } \\
\text { followed by } \\
\text { fluconazole. }\end{array}$ & $\begin{array}{l}2.5 \mu \mathrm{g} \text { of Human IL-7 } \\
\text { (Cytheris) for } 5 \mathrm{~d} \text {, } \\
4 \mathrm{~d} \text { postsurgery and } 1 \mathrm{~d} \text { after } \\
\text { secondary challenge. A group } \\
\text { also received a concomitant } \\
\text { dose of } 200 \mu \mathrm{g} \text { of anti-PD1 } \\
\text { (Bio X Cell) on both the first } \\
\text { and the last day of treatment. }\end{array}$ & $\begin{array}{l}\text {-bCell Proliferation (Ki67); } \\
\text { - Activation (IFN- } \gamma \text { ); } \\
\text { - Surface Markers (LFA-1, VLA-4, CD28); } \\
\text { - Innate Immunity (MHC II expression). }\end{array}$ \\
\hline $\begin{array}{l}\text { Shindo et } \\
\text { al. }{ }^{14} \\
2017\end{array}$ & $\begin{array}{l}\text { C57BL/6 } \\
\text { mice. }\end{array}$ & $\begin{array}{l}\text { Cecal ligation } \\
\text { and puncture } \\
\text { (CLP) followed } \\
\text { by imipenem. } \\
\text { Intratracheal } \\
P \text {. Aeruginosa } \\
\text { followed by } \\
\text { imipenem. }\end{array}$ & $\begin{array}{l}2.5 \mu \mathrm{g} \text { of human rIL-7 } \\
\text { (Revimmune) for } 6 \mathrm{~d} \text { post } \\
\text { surgery. Secondary challenge } \\
3 \mathrm{~d} \text { post surgery. }\end{array}$ & $\begin{array}{l}\text { - Survival Protocol } \\
\text { - Cell Count (CD4, CD8, NKT and } \gamma \delta \\
\text { T-cells); } \\
\text { - Cell Proliferation (Ki67), } \\
\text { - Activation (IL-17, IL-22, IFN- } \gamma \text {, TNF- } \alpha \text {, } \\
\text { NF-kB activation and phosphorylated } \\
\text { STAT3 expression); } \\
\text { - Innate Immunity (NK, IL2, IL3). }\end{array}$ \\
\hline $\begin{array}{l}\text { Kulkarni } \\
\text { et al. }{ }^{15} \\
2018\end{array}$ & $\begin{array}{l}\text { C57BL/6 } \\
\text { mice. }\end{array}$ & $\begin{array}{l}\text { Intraperitoneal } \\
\text { human feces } \\
\text { followed by } \\
\text { meropenem. }\end{array}$ & $\begin{array}{l}2.5 \mu \mathrm{g} \text { of antibody stabilized } \\
\text { human rIL-7 (R\&D Systems) } \\
\text { for } 5 \mathrm{~d}, 5 \mathrm{~d} \text { post surgery. }\end{array}$ & $\begin{array}{l}\text { - Cell Count (IL-10+ B, DN T, MDSC); } \\
\text { - Cell Proliferation (CD4 T cells under } \\
\text { MDSC). }\end{array}$ \\
\hline
\end{tabular}

Table 2: Ex vivo studies

\begin{tabular}{|l|l|l|l|l|l|}
\hline Sources & Population & Exclusion criteria & $\begin{array}{l}\text { Blood } \\
\text { Samples }\end{array}$ & Follow up & Assessments \\
\hline $\begin{array}{l}\text { Venet et } \\
\text { al. }{ }^{16} \\
2012\end{array}$ & $\begin{array}{l}70 \text { septic } \\
\text { shock patients; } \\
55 \text { healthy } \\
\text { volunteers. }\end{array}$ & Not reported. & $\begin{array}{l}\text { Day 1-2 and } \\
\text { day 3-4 after } \\
\text { shock. }\end{array}$ & $\begin{array}{l}\text { 28 days } \\
\text { (mortality: } \\
\text { 24, secondary } \\
\text { infections: 14). }\end{array}$ & $\begin{array}{l}\text { - Cell Proliferation } \\
\text { - Apoptosis (Bcl2); } \\
\text { - Activation (IFN- } \gamma \text {; STAT5 } \\
\text { phosphorylation). }\end{array}$ \\
\hline $\begin{array}{l}\text { Demaret et } \\
\text { al. }{ }^{17} \\
2015\end{array}$ & $\begin{array}{l}13 \text { septic } \\
\text { shock patients; } \\
10 \text { healthy } \\
\text { volunteers. }\end{array}$ & $\begin{array}{l}\text { Younger than 18y, aplasia } \\
\text { or immunosuppressive } \\
\text { disease (e.g., HIV } \\
\text { infection). }\end{array}$ & $\begin{array}{l}\text { Day 3-4 after } \\
\text { shock. }\end{array}$ & $\begin{array}{l}\text { 28 days } \\
\text { (mortality: 5). }\end{array}$ & $\begin{array}{l}\text { - Activation (STAT5 } \\
\text { phosphorylation). }\end{array}$ \\
\hline $\begin{array}{l}\text { Venet et } \\
\text { al. }{ }^{18} \\
2017\end{array}$ & $\begin{array}{l}75 \text { septic } \\
\text { shock patients; } \\
25 \text { healthy } \\
\text { volunteers. }\end{array}$ & $\begin{array}{l}\text { Younger than 18y, aplasia } \\
\text { or immunosuppressive } \\
\text { disease (e.g., HIV } \\
\text { infection). }\end{array}$ & $\begin{array}{l}\text { Day 3-4 after } \\
\text { shock. }\end{array}$ & $\begin{array}{l}\text { 28 days } \\
\text { (mortality: 18). }\end{array}$ & $\begin{array}{l}\text { - Activation (metabolites } \\
\text { concentration, metabolic } \\
\text { pathways). }\end{array}$ \\
\hline $\begin{array}{l}\text { Thampy et } \\
\text { al. }{ }^{19} \\
2018\end{array}$ & $\begin{array}{l}\text { 24 multi-drug } \\
\text { resistant bacteria } \\
\text { septic patients; } \\
\text { 26 critically-ill } \\
\text { non-septic } \\
\text { patients. }\end{array}$ & $\begin{array}{l}\text { Younger than 18 y, HIV, } \\
\text { organ or bone marrow } \\
\text { transplantation, high-dose } \\
\text { corticosteroid regimens, } \\
\text { immune-modifying } \\
\text { biological agents, systemic } \\
\text { autoimmune diseases. }\end{array}$ & $\begin{array}{l}\text { 24-48 hours } \\
\text { after positive } \\
\text { cultures for } \\
\text { multi-drug } \\
\text { resistant } \\
\text { bacteria. }\end{array}$ & $\begin{array}{l}\text { Patient survival } \\
\text { was followed } \\
\text { for 90 days } \\
\text { after study } \\
\text { entry. }\end{array}$ & - Activation (IFN- $\gamma$ ). \\
\hline
\end{tabular}

\section{Animals Studies}

Most of the animals studied were C57BL6 (inbred) or CD1 (outbred) male mice, although a single source utilized knockout mice for both $\alpha \beta$ and $\gamma \delta$ TCR or just $\gamma \delta$ TCR, so as to evaluate the pathway of IL-7 action ${ }^{11}$. As for the model of sepsis, two studies employed the usual colon puncture and ligation method without any other further procedure, in an attempt to assess IL-7 ability to prevent septic immunosuppression ${ }^{10,11}$. Three other sources applied intravenous antibiotic treatment (imipenem) right away after the surgery, mimicking hospitalized care. The mice were then challenged again with common nosocomial pathogens (C. albicans and P. Aeruginosa), in an effort to recreate secondary infections commonly associated with sepsis and thus to study IL-7 capabilities to reverse immunosuppression after it has been $\operatorname{set}^{12-14}$. Finally, the remaining source resorted to intraperitoneal injection of a solution of human feces, followed by treatment with meropenem ${ }^{15}$. There were various drug regimens, but doses were either $2.5 \mathrm{mg}$ or $5 \mathrm{mg}$ of recombinant IL-7 stabilized with antibodies (R\&D Systems) or rIL-7 of longer half-life (Cytheris) $^{10}$. 
As for the bias assessment of animal studies, all interventions had control groups, usually for both sepsis (versus sham surgery) and IL-7 administration. There was no blinding. Certainty was evaluated by the sound proposed methods, result presentation and commentary.

\section{IL-7 improved survival}

Three studies carried out sepsis survival protocols. IL-7 improved survival in both CLP mice (two or three doses of $5 \mu \mathrm{g}$; total $\mathrm{n}=149$; follow-up for 7 days $)^{10}$ and CLP mice secondarily challenged with peritonitis (five doses of $2.5 \mu \mathrm{g}, \mathrm{n}=75$, follow-up for 14 days $)^{13}$ and pneumonia (six doses of $5 \mu \mathrm{g}$; total $\mathrm{n}=50$, follow-up for 12 days) ${ }^{14}$. However, IL-7 failed to change outcomes for mice without functional T-cell receptors (TCR $\alpha \beta / \gamma \delta$ knockout) ${ }^{11}$.

\section{IL-7 improved lymphoid cell count and proliferation}

Four out of the six sources on animal models performed lymphocyte proliferation test, using Ki-67 as marker. Most of them showed marked T cell proliferation for both CD4+ and CD8+ subsets $(10,12,13)$, although in a single study treatment with IL-7 did not show effect on the percentage of Ki-67 displaying of CD4+ T cells ${ }^{10}$. Higher $\mathrm{Ki}-67$ expression was also detected on naive (non septic) mice treated with IL- $7^{14}$. A more evident effect was seen in peripheral lymph node cells than splenocytes in one of the peritonitis models ${ }^{13}$, while the pneumonia model showed similar effects to both spleen and lung lymphocyte Ki-67 expression $^{14}$.

Total cell count was reported in most of the sources. IL-7 treatment had positive effect on the absolute number of various subsets of $\mathrm{T}$ lymphocytes, such as naive, central memory and effector memory CD4+ T cells ${ }^{10}$; central memory and effector memory CD8+ T cells ${ }^{10}$; and peritoneal $\gamma \delta \mathrm{T}$ cells ${ }^{11}$. IL-7 expanded cell numbers of other lymphoid cell lineages such as NKT cells, NK cells, ILC2 and ILC3 in naive mice ${ }^{14}$, but had no effect on the depletion of NK cells, B cells and dendritic cells of septic mice ${ }^{10}$. There was some divergence in cell counts results, as in one peritonitis study, IL-7 did not improve central memory CD4 $+\mathrm{T}$ count $^{13}$, while in another CLP model it instead failed to increase naive $\mathrm{CD} 8+\mathrm{T}$ cells ${ }^{10}$. On the other hand, IL-7 also induced a transient expansion of anti-inflammatory cells, such as Foxp3+, CD25+, CD4+ T cells, Double negative CD3+,CD4-,CD8- T cells and MDSC (myeloid-derived suppressor cells) ${ }^{15}$.

\section{functionality \\ IL-7 improved lymphocyte activation and}

Treatment with IL-7 improved IFN- $\gamma$ production level in several studies, with a tendency to a more pronounced effect in CD8 $+\mathrm{T}$ cells rather than $\mathrm{CD} 4+\mathrm{T}$ cells $^{10,12-14}$. However, IL-7 effects on IFN- $\gamma$ seemed to be restricted to lymphocytes, as it failed to improve NK cells production of IFN- $\gamma^{13}$. The therapy also did not show any effect on plasma IFN- $\gamma$ levels ${ }^{14}$. In relation to other cytokines, IL-7 increased the number of IL-17- and TNF- $\alpha$ producing ILCs and CD8 T cells in the lungs of septic mice challenged with pneumonia, and that of IL-17-, TNF- $\alpha-$ and IL-22-producing ILCs and T cells in their spleens ${ }^{14}$. Moreover, IL-7 treatment showed increased levels of transcription factors NF- $\kappa \mathrm{B}$ and STAT $3{ }^{14}$.

IL-7 also improved the expression of cell trafficking molecules of lymphocytes. Relative expression of integrins LFA-1 and VLA-4 on CD4+ and CD8+ were higher for both septic and naive mice treated with IL-7(10, 12). IL-7 and combination of IL-7 and anti-PD-1 increased LFA-1 of splenic CD4 and CD8 T cells and CD4 T cells positive for VLA-4, but not CD8+ T cells ${ }^{13}$.

IL-7 treatment was responsible for a spike in serum IL-6 levels, although not lasting (effect evaluated by 6 hours, no difference at the $24 \mathrm{~h}$ mark $)^{11}$. The intervention also did not affect circulating levels of other inflammatory cytokines such as IL-17, IL-22 and TNF- $\alpha^{14}$. Supernatants of splenocytes, however, showed increased production of cytokines such as IL-2, IL-6 and TNF- $\alpha$, but not of IL-10 ${ }^{12}$.

Among other markers of lymphocyte activation and functionality, IL-7 increased CD8 expression in sham, septic $^{10}$ and 2-hit mice ${ }^{13}$, but the treatment did not expand septic mice CD4 expression ${ }^{10}$. CD69, a routinely used marker of activation, was shown to be increased by IL-7 treatment in CD8+ T cells, and reversed to pre-sepsis levels in $\mathrm{CD} 4+\mathrm{T}$ cells, in one of the peritonitis model ${ }^{13}$.

Finally, sepsis-induced expansion of the IL-7R, as a homeostatic mechanism for replenishment of lost immune cells, is reversed by IL-7 administration, leading to receptor downregulation and probably accounting for the treatment lack of exacerbated inflammatory response ${ }^{10}$.

\section{IL-7 prevented apoptosis}

Treatment with IL-7 induced the upregulation of the anti-apoptotic protein Blc- 2 in T cells ${ }^{10,11}$, and prevented the sepsis-induced upregulation of proapoptotic PUMA protein in both in vivo and ex vivo experiments ${ }^{10}$. IL-7 also showed marked reduction of both CD4+ and CD8+ T cell apoptosis as measured by the TUNNEL method ${ }^{10}$.

\section{IL-7 improved innate immune response and} pathogen clearance.

Mice treated with IL-7 showed increased cell count of a number of innate immunity cells, such as splenic NK cells, ILC2 and ILC $3{ }^{14}$. Early neutrophil recruitment was shown to be increased by IL-7 administration, although no significant difference in the local population of cells was seen at the $24 \mathrm{~h}$ mark, nor did the treatment improve their activation, as evaluated by phagocytosis, oxidative burst and CD11b expression ${ }^{11}$. Another marker of innate immune activation, class II major histocompatibility complex expression on macrophages and dendritic cells, was also not significantly increased by IL- $7^{13}$. As for specific pathogen 
burden, IL-7 administration reduced both bacteremia at the $24 \mathrm{~h}$ mark $^{11}$ and the number of liver Candida foci ${ }^{12}$.

\section{IL-7 restored delayed type hypersensitivity, but} caused no end-organ injury

The loss of delayed type hypersensitivity seen in septic mice was reversed by IL-7 treatment, as measured by footpad swelling to trinitrophenyl in both CPL-only ${ }^{10}$ and peritonitis models ${ }^{12}$. Nonetheless, several markers of tissue damage, such as lung myeloperoxidase, serum aspartate aminotransferase and intestinal wet/dry ratio were not significantly increased by IL- treatment ${ }^{11}$.

\section{Individual result tables}

The individual results for each study are summarized in Tables 3 to 8 .

Table 3: Results from Unsinger et al. ${ }^{10}$

\begin{tabular}{|c|c|c|c|c|}
\hline Assessment & Sample and Grouping & Intervention & Outcome & p-value \\
\hline Overall survival. & $\begin{array}{l}\mathrm{n}=14,25 \text { and } 31 \text { per } \\
\text { CLP group. } \mathrm{n}=14,24 \\
\text { and } 31 \text { per CLP+IL-7 } \\
\text { group. }\end{array}$ & $\begin{array}{l}5 \mu \mathrm{g} \text { of rhIL- } 7 \text { or saline } 90 \\
\text { min, } 24 \mathrm{~h} \text { and } 48 \mathrm{~h} \text { after CLP } \\
\text { surgery. }\end{array}$ & $\begin{array}{l}\text { IL-7 treatment markedly improved } \\
\text { survival in sepsis. }\end{array}$ & $\begin{array}{l}p<0.01- \\
0.03\end{array}$ \\
\hline $\begin{array}{l}\text { Splenic cell } \\
\text { count. }\end{array}$ & $\begin{array}{l}\text { n=11 per group (sham; } \\
\text { sham+IL-7; CLP; } \\
\text { CLP+IL-7). }\end{array}$ & $\begin{array}{l}5 \mu \mathrm{g} \text { of rhIL- } 7 \text { or saline } \\
90 \text { min after CLP surgery. } \\
\text { Spleens were harvested after } \\
24 \mathrm{~h} .\end{array}$ & $\begin{array}{l}\text { IL- } 7 \text { treatment prevented the decrease } \\
\text { in CD4+ and CD8+ T cells, but not in } \\
\text { NK cells, B cells, or dendritic cells in } \\
\text { CLP mice spleens. }\end{array}$ & $\begin{array}{l}p<0.01- \\
0.05\end{array}$ \\
\hline $\begin{array}{l}\text { Lymph node cell } \\
\text { count. }\end{array}$ & $\begin{array}{l}n=6 \text { per sham group. } \\
n=9-10 \text { per CLP group. }\end{array}$ & $\begin{array}{l}5 \mu \mathrm{g} \text { of rhIL-7, } 90 \text { min after } \\
\text { CLP surgery. Mesenteric } \\
\text { lymph nodes were harvested } \\
\text { after } 24 \mathrm{~h} .\end{array}$ & $\begin{array}{l}\text { IL- } 7 \text { treatment had a significant } \\
\text { ability to increase the absolute cell } \\
\text { counts of all lymphocyte groups } \\
\text { (naive, effector and memory) but } \\
\text { naive CD8+ T cells in CLP mice } \\
\text { lymph nodes. }\end{array}$ & $p<0.05$ \\
\hline Apoptosis & $\begin{array}{l}n=6-8 \text { per sham group. } \\
n=11 \text { per CLP group. }\end{array}$ & $\begin{array}{l}5 \mu \mathrm{g} \text { of rhIL-7, } 90 \mathrm{~min} \text { after } \\
\text { CLP surgery. Spleens were } \\
\text { harvested after } 24 \mathrm{~h} .\end{array}$ & $\begin{array}{l}\text { IL- } 7 \text { treatment prevented the increase } \\
\text { in CD4+ and CD8+ T cell apoptosis } \\
\text { occurring during sepsis in CLP mice } \\
\text { spleens. }\end{array}$ & $\begin{array}{l}p<0.01- \\
0.05\end{array}$ \\
\hline $\begin{array}{l}\text { Intracellular } \\
\text { markers (Bcl-2 } \\
\text { and PUMA). }\end{array}$ & $\begin{array}{l}\mathrm{n}=6-8 \text { per group (sham; } \\
\text { sham+IL-7; CLP; } \\
\text { CLP+IL-7). }\end{array}$ & Same as above. & $\begin{array}{l}\text { IL-7 treatment increased Bcl-2 } \\
\text { expression in CD4+ and CD8+ } \\
\text { T cells in CLP mice spleens. } \\
\text { IL-7 also prevented the increase } \\
\text { of proapoptotic PUMA protein } \\
\text { expression in CD4+ T cells. }\end{array}$ & $p<0.05$ \\
\hline $\begin{array}{l}\text { Splenic T cell } \\
\text { proliferation. }\end{array}$ & $\begin{array}{l}\mathrm{n}=6-7 \text { per group (sham; } \\
\text { sham+IL-7; CLP; } \\
\text { CLP+IL-7). }\end{array}$ & $\begin{array}{l}5 \mu \mathrm{g} \text { of rhIL- } 7,90 \mathrm{~min}, 24 \mathrm{~h} \\
\text { and } 48 \mathrm{~h} \text { after CLP surgery. } \\
\text { Spleen were harvested after } \\
72 \mathrm{~h} .\end{array}$ & $\begin{array}{l}\text { IL- } 7 \text { treatment increased the } \\
\text { proliferation of CD8+ (but not } \\
C D 4+) \text { T cells in CLP mice spleens. }\end{array}$ & $p<0.001$ \\
\hline $\begin{array}{l}\text { Surface markers } \\
\text { (IL-7R). }\end{array}$ & $\begin{array}{l}\text { n=4 per group (sham; } \\
\text { sham+IL-7; CLP; } \\
\text { CLP+IL-7). }\end{array}$ & $\begin{array}{l}5 \mu \mathrm{g} \text { of rhIL- } 7 \text { for } 3 \\
\text { consecutive days. Spleens } \\
\text { were harvested on the third } \\
\text { postoperative day. }\end{array}$ & $\begin{array}{l}\text { IL- } 7 \text { treatment reverted the sepsis- } \\
\text { induced increase in IL-7R expression } \\
\text { by CD4+ and CD8+ T cells in CLP } \\
\text { mice. }\end{array}$ & $\begin{array}{l}p<0.01- \\
0.05\end{array}$ \\
\hline $\begin{array}{l}\text { Activation } \\
(\text { IFN- } \gamma)\end{array}$ & $\begin{array}{l}\mathrm{n}=8-9 \text { per group (sham; } \\
\text { sham+IL-7; CLP; } \\
\text { CLP+IL-7). }\end{array}$ & $\begin{array}{l}5 \mu \mathrm{g} \text { of rhIL- } 7 \text { or saline } 90 \\
\text { min after surgery. Spleens } \\
\text { were harvested after } 24 \mathrm{~h} \text {. }\end{array}$ & $\begin{array}{l}\text { IL- } 7 \text { prevented the decrease in IFN- } \gamma \\
\text { production in splenic T cells (CD4+, } \\
\text { CD8+ and CD62L+) in CLP mice. }\end{array}$ & $p<0.05$ \\
\hline $\begin{array}{l}\text { Surface markers } \\
\text { (LFA-1, VLA-4, } \\
\text { CD4 and CD8). }\end{array}$ & $\begin{array}{l}n=10(\text { sham }) \\
n=9(\text { sham }+ \text { IL-7) } \\
n=13(\text { CLP mice }) \\
n=12(\text { CLP }+ \text { IL-7) }\end{array}$ & $\begin{array}{l}5 \mu \mathrm{g} \text { of rhIL- } 7,90 \mathrm{~min}, \\
24 \mathrm{~h} \text { and } 48 \mathrm{~h} \text { after surgery. } \\
\text { Spleens were harvested after } \\
72 \mathrm{~h} .\end{array}$ & $\begin{array}{l}\text { IL- } 7 \text { treatment increased LFA-1, } \\
\text { VLA-4 and CD8 expression (but not } \\
\text { CD4 expression) in CLP mice. }\end{array}$ & $p<0.05$ \\
\hline $\begin{array}{l}\text { Delayed-type } \\
\text { hypersensitivity } \\
\text { (DTH) response. }\end{array}$ & $\begin{array}{l}\mathrm{n}=5 \text { per group (sham; } \\
\text { sham+IL-7; CLP; } \\
\text { CLP+IL-7). }\end{array}$ & $\begin{array}{l}2.5 \mu \mathrm{g} \text { of rhIL- } 7,90 \\
\text { min after surgery and } 2 \\
\text { additional doses every } 48 \mathrm{~h} \text {. } \\
\text { Mice were sensitized four } \\
\text { days post surgery }\end{array}$ & $\begin{array}{l}\text { IL- } 7 \text { treatment prevented the loss of } \\
\text { DTH response in CLP mice. }\end{array}$ & $p<0.05$ \\
\hline
\end{tabular}


Table 4: Results from Kasten et al. ${ }^{11}$

\begin{tabular}{|c|c|c|c|c|}
\hline Assessment & $\begin{array}{l}\text { Sample and } \\
\text { Grouping }\end{array}$ & Intervention & Outcome & p-value \\
\hline $\begin{array}{l}\text { Overall survival } \\
\text { (TCR } \alpha \beta / \gamma \delta- \\
\text { deficient mice). }\end{array}$ & $\begin{array}{l}\mathrm{n}=10-11 \text { per } \\
\text { group (WT; IL-7). }\end{array}$ & $\begin{array}{l}\text { Mice were treated with either } 5 \mu \mathrm{g} \\
\text { of rhIL-7 or vehicle at the time of } \\
\text { CLP. }\end{array}$ & $\begin{array}{l}\text { IL- } 7 \text { treatment did not improve the } \\
\text { survival of TCR } \alpha \beta / \gamma \delta \text {-deficient } \\
\text { mice. }\end{array}$ & - \\
\hline $\begin{array}{l}\text { Intracellular } \\
\text { markers (Bcl-2). }\end{array}$ & $\begin{array}{l}\mathrm{n}=4 \text { per group } \\
\text { (sham; sham+IL7; } \\
\text { CLP; CLP+IL7). }\end{array}$ & $\begin{array}{l}\text { Mice were treated with either } 5 \mu \mathrm{g} \\
\text { of rhIL-7 or vehicle at the time of } \\
\text { CLP. Spleens were harvested } 3 \mathrm{~h} \\
\text { after CLP. }\end{array}$ & $\begin{array}{l}\text { IL- } 7 \text { treatment elevates Bcl-2 } \\
\text { expression in CD4+ naive and } \\
\text { effector memory T cells, and CD8+ } \\
\text { T naive cells. }\end{array}$ & $p<0.05$ \\
\hline $\begin{array}{l}\text { Activation } \\
(\text { IFN- } \gamma)\end{array}$ & $\begin{array}{l}\mathrm{n}=8 \text { per group } \\
\text { (WT;IL-7). }\end{array}$ & $\begin{array}{l}\text { Mice were treated with } 5 \mu \mathrm{g} \text { of rhIL- } \\
7 \text { at the time of CLP. Splenocytes } \\
\text { were obtained } 3 \mathrm{~h} \text { after CLP. }\end{array}$ & $\begin{array}{l}\text { IL- } 7 \text { treatment enhances IFN- } \gamma \\
\text { levels in septic mice. }\end{array}$ & $p<0.05$ \\
\hline $\begin{array}{l}\text { Humoral marker } \\
\text { (CXCL10/IP- } \\
\text { 10). }\end{array}$ & $\begin{array}{l}\mathrm{n}=4 \text { per group } \\
(\text { sham, sham+IL } 7, \\
\text { CLP, CLP+IL 7). }\end{array}$ & $\begin{array}{l}\text { Mice were treated with } 5 \mu \mathrm{g} \text { of } \\
\text { rhIL- } 7 \text { at the time of CLP. Peritoneal } \\
\text { lavage fluid obtained } 3 \mathrm{~h} \text { after CLP. }\end{array}$ & $\begin{array}{l}\text { IL-7 treatment promoted increased } \\
\text { concentrations of peritoneal } \\
\text { CXCL10/IP-10. }\end{array}$ & $p<0.01$ \\
\hline $\begin{array}{l}\text { Innate immunity } \\
\text { (neutrophil } \\
\text { recruitment). }\end{array}$ & $\begin{array}{l}\mathrm{n}=9-13(6 \mathrm{~h} \text { WT } \\
\text { and IL-7). } \mathrm{n}=12- \\
13(24 \mathrm{hWT} \text { and } \\
\text { IL-7). }\end{array}$ & $\begin{array}{l}\text { Mice were treated with } 5 \mu \mathrm{g} \text { of rhIL- } \\
7 \text { at the time of CLP. Neutrophils at } \\
\text { the site of infection were analyzed at } \\
\text { the indicated times following CLP. }\end{array}$ & $\begin{array}{l}\text { IL- } 7 \text { treatment enhances neutrophil } \\
\text { recruitment to the peritoneum of } \\
\text { septic mice. IL-7, however, did not } \\
\text { increase activation or functionality } \\
\text { of neutrophils. }\end{array}$ & $p<0.01$ \\
\hline $\begin{array}{l}\text { Cell count }(\gamma \delta \\
\text { T cells) and } \\
\text { Activation (IL- } \\
17) \text {. }\end{array}$ & $\begin{array}{l}\mathrm{n}=4 \text { per group } \\
\text { (WT; IL-7). }\end{array}$ & $\begin{array}{l}\text { Mice were treated with } 5 \mu \mathrm{g} \\
\text { human of rhIL- } 7 \text { at the time of } \\
\text { CLP. Peritoneal } \gamma \delta \mathrm{T} \text { at the site of } \\
\text { infection were analyzed } 3 \mathrm{~h} \text { after } \\
\text { CLP }\end{array}$ & $\begin{array}{l}\text { IL- } 7 \text { treatment increased the } \\
\text { number of IL-17-producing } \\
\text { peritoneal } \gamma \delta \text { T cells in septic mice. } \\
\text { IL-17 secretion was also increased } \\
\text { by the treatment. }\end{array}$ & $p<0.05$ \\
\hline $\begin{array}{l}\text { Humoral } \\
\text { markers } \\
(\mathrm{CXCL} 1)\end{array}$ & $\begin{array}{l}\mathrm{n}=11-14 \text { per } \\
\text { group (WT; IL-7). }\end{array}$ & $\begin{array}{l}\text { Mice were treated with } 5 \mu \mathrm{g} \text { human } \\
\text { of rhIL- } 7 \text { at the time of CLP. } \\
\text { Peritoneal lavage fluid obtained } 6 \mathrm{~h} \\
\text { after CLP. }\end{array}$ & $\begin{array}{l}\text { IL-7 treatment promoted increased } \\
\text { concentrations of peritoneal } \\
\text { CXCL1. }\end{array}$ & $p<0.01$ \\
\hline $\begin{array}{l}\text { Humoral } \\
\text { markers (IL-6). }\end{array}$ & $\begin{array}{l}\mathrm{n}=8-11 \text { per group } \\
\text { (WT 6h, WT } 24 \mathrm{~h} ; \\
\text { IL-7 6h; IL-7 } \\
\text { 24h). }\end{array}$ & $\begin{array}{l}\text { Mice were treated with } 5 \mu \mathrm{g} \text { human } \\
\text { of rhIL- } 7 \text { at the time of CLP. Sera } \\
\text { were obtained at the indicated time } \\
\text { points. }\end{array}$ & $\begin{array}{l}\text { IL- } 7 \text { treatment significantly } \\
\text { increased IL- } 6 \text { serum levels at } 6 \mathrm{~h} \text {, } \\
\text { but not at } 24 \mathrm{~h} \text {. }\end{array}$ & $p<0.001$ \\
\hline $\begin{array}{l}\text { Pathogen } \\
\text { burden }\end{array}$ & $\begin{array}{l}\mathrm{n}=8-11 \text { per group } \\
\text { (WT and IL-7). }\end{array}$ & $\begin{array}{l}\text { Mice were treated with } 5 \mu \mathrm{g} \text { of } \\
\text { rhIL-7 at the time of CLP. Serum } \\
\text { bacterial loads were measured } 24 \mathrm{~h} \\
\text { after induction of sepsis. }\end{array}$ & $\begin{array}{l}\text { IL-7 treatment significantly } \\
\text { lowered blood bacterial load. }\end{array}$ & $p<0.05$ \\
\hline $\begin{array}{l}\text { Tissue } \\
\text { damage (AST, } \\
\text { pulmonary } \\
\text { MPO and } \\
\text { intestinal dry/ } \\
\text { wet ratio). }\end{array}$ & $\begin{array}{l}\mathrm{n}=8-11 \text { per group } \\
\text { (WT 6h, WT } 24 \mathrm{~h} ; \\
\text { IL-7 6h; IL-7 } \\
\text { 24h). }\end{array}$ & $\begin{array}{l}\text { Mice were treated with } 5 \mu \mathrm{g} \text { of } \\
\text { rhIL- } 7 \text { at the time of CLP. Serum } \\
\text { AST levels were measured } 24 \mathrm{~h} \\
\text { after induction of sepsis. Lungs and } \\
\text { terminal ilea were obtained at the } \\
\text { indicated time points. }\end{array}$ & $\begin{array}{l}\text { IL- } 7 \text { treatment did not significantly } \\
\text { promote inflammation (as } \\
\text { measured by AST, pulmonary } \\
\text { MPO and intestinal dry/wet ratio) } \\
\text { compared to controls. }\end{array}$ & - \\
\hline
\end{tabular}


Moraes FOC, et al. Effects of IL-7 on sepsis: a systematic review

Table 5: Results from Unsinger et al. ${ }^{12}$

\begin{tabular}{|c|c|c|c|c|}
\hline Assessment & Sample and Grouping & Intervention & Outcome & $p$-value \\
\hline Overall Survival. & $\begin{array}{l}\mathrm{n}=25 \text { (control) } \\
\mathrm{n}=30 \text { (IL-7). }\end{array}$ & $\begin{array}{l}\text { Mice were treated with } 2.5 \mu \mathrm{g} \text { of IL- } 7 \\
\text { daily for } 5 \text { days, starting on day } 6 \text { post- } \\
\text { CLP. Candida infection was conducted } 4 \\
\text { days after CLP. }\end{array}$ & $\begin{array}{l}\text { IL-7 treated mice had improved } \\
\text { survival. }\end{array}$ & $p<0.02$ \\
\hline $\begin{array}{l}\text { Delayed-type } \\
\text { hypersensitivity } \\
\text { (DTH) response. }\end{array}$ & $\begin{array}{l}\mathrm{n}=5-9 \text { per group }(\text { control; } \\
\text { CLP }+ \text { Candida } \text { CLP }+ \\
\text { Candida }+ \text { IL-7). }\end{array}$ & $\begin{array}{l}\text { Mice were treated with } 2.5 \mu \mathrm{g} \text { of IL- } 7 \\
\text { daily for } 5 \text { days, starting on day } 6 \text { post- } \\
\text { CLP. Candida infection was conducted } \\
4 \text { days after CLP. Mice were challenged } \\
\text { with } 2,4,6 \text {-trinitrobenzenesulfonic acid } \\
\text { (TNBS) (concentration of } 10 \mathrm{mM}) \text { on days } \\
7(100 \mu \mathrm{L}) \text { and } 11(30 \mu \mathrm{L}) \text {. Footpad was } \\
\text { measured on day } 12 \text {. }\end{array}$ & $\begin{array}{l}\text { IL-7 treatment improved DTH } \\
\text { response in septic mice. }\end{array}$ & $p<0.03$ \\
\hline Spleen cell count. & $\begin{array}{l}\mathrm{n}=9(\text { control }) \\
\mathrm{n}=14(\text { CLP }+ \text { Candida }) \\
\mathrm{n}=18(\mathrm{CLP}+\text { Candida }+ \\
\text { IL-7). }\end{array}$ & $\begin{array}{l}\text { Mice were treated with } 2.5 \mu \mathrm{g} \text { of IL- } 7 \\
\text { daily for } 5 \text { days, starting on day } 6 \text { post- } \\
\text { CLP. Candida infection was conducted } 4 \\
\text { days after CLP. Spleens were harvested } \\
\text { on day } 11 .\end{array}$ & $\begin{array}{l}\text { IL- } 7 \text { treatment improved the cell } \\
\text { count of all groups (naive, effector } \\
\text { memory and central memory) of } \\
\text { CD } 8+\text { T cells. Central memory CD4+ } \\
\text { T cell count was not significantly } \\
\text { altered. }\end{array}$ & $p<0.05$ \\
\hline $\begin{array}{l}\text { Cell activation } \\
\text { (CD69) and } \\
\text { proliferation } \\
\text { (Ki67). }\end{array}$ & $\begin{array}{l}\mathrm{n}=5-9 \text { per group (control, } \\
\text { CLP }+ \text { Candida, CLP }+ \\
\text { Candida }+ \text { IL-7). }\end{array}$ & Same was above. & $\begin{array}{l}\text { IL-7 treatment increased in } \\
\text { proliferation (positivity for Ki67) and } \\
\text { activation (positivity for CD69) in } \\
\text { CD4+ and CD8+ T cells. }\end{array}$ & $p<0.02$ \\
\hline $\begin{array}{l}\text { Surface markers } \\
\text { (LFA-1). }\end{array}$ & $\begin{array}{l}\mathrm{n}=9-18 \text { per group } \\
\text { (control; CLP+Candida; } \\
\text { CLP+ Candida }+ \text { IL-7). }\end{array}$ & Same was above. & $\begin{array}{l}\text { IL-7 treatment upregulated the } \\
\text { expression of LFA-1 on CD4+ and } \\
\text { CD8+ T cells. }\end{array}$ & $p<0.01$ \\
\hline $\begin{array}{l}\text { Activation (IL-2, } \\
\text { IFN- } \gamma \text {, TNF- } \alpha \text {, } \\
\text { IL-6) }\end{array}$ & $\begin{array}{l}\mathrm{n}=5-9 \text { per group (control; } \\
\text { CLP+ Candida; CLP+ } \\
\text { Candida }+ \text { IL-7). }\end{array}$ & $\begin{array}{l}\text { Mice were treated with } 2.5 \mu \mathrm{g} \text { of IL- } 7 \\
\text { daily for } 5 \text { days, starting on day } 6 \text { post- } \\
\text { CLP. Candida infection was conducted } 4 \\
\text { days after CLP. Spleens were harvested } \\
\text { on day } 11.10 \text { million splenocytes were } \\
\text { stimulated with CD } 3 \text { and CD } 28 \text { overnight. } \\
\text { Supernatants were harvested at } 18 \text { hours. }\end{array}$ & $\begin{array}{l}\text { IL- } 7 \text { treatment increased IL-2, IFN- } \gamma \text {, } \\
\text { TNF- } \alpha \text { and IL- } 6 \text { production. }\end{array}$ & $p<0.01-0.05$ \\
\hline Pathogen burden & $\begin{array}{l}\mathrm{n}=5-9 \text { per group (control; } \\
\text { CLP+ Candida; CLP+ } \\
\text { Candida+ IL-7). }\end{array}$ & $\begin{array}{l}\text { Mice were treated with } 2.5 \mu \mathrm{g} \text { of IL- } 7 \\
\text { daily for } 5 \text { days, starting on day } 6 \text { post- } \\
\text { CLP. Candida infection was conducted } \\
4 \text { days after CLP. Kidneys and livers } \\
\text { were homogenized } 3 \text { days post-Candida } \\
\text { injection. }\end{array}$ & $\begin{array}{l}\text { IL-7 treatment reduced the number } \\
\text { of Candida colony-forming units. }\end{array}$ & $p<0.007$ \\
\hline
\end{tabular}

Table 6: Results from Shindo et al. ${ }^{13}$

\begin{tabular}{|l|l|l|l|l|}
\hline Assessment & $\begin{array}{l}\text { Sample and } \\
\text { Grouping }\end{array}$ & Intervention & Outcome & $p$-value \\
\hline $\begin{array}{l}\text { Surface markers (Class } \\
\text { II MHC). }\end{array}$ & $\begin{array}{l}\mathrm{n}=29 \text { (control). } \\
\mathrm{n}=30 \text { (IL-7). }\end{array}$ & $\begin{array}{l}\text { Mice were treated with 2.5 } \mu \text { g of IL-7 } \\
\text { daily for 5 days, starting on day 4 post- } \\
\text { CLP. Candida infection was conducted } \\
\text { 3 days after CLP. Spleens and peripheral } \\
\text { lymph nodes were harvested on day 9. }\end{array}$ & $\begin{array}{l}\text { Mice that received treatment with } \\
\text { IL-7 had lower MHC II MFI (mean } \\
\text { fluorescent intensity) compared to } \\
\text { controls. }\end{array}$ & $p<0.01$ \\
\hline $\begin{array}{l}\text { Surface markers } \\
\text { (CD28). }\end{array}$ & Same as above. & Same as above. & $\begin{array}{l}\text { IL-7 treatment increased the } \\
\text { percentage of splenic CD8+ T cells } \\
\text { positive for CD28 compared to an } \\
\text { alternative therapy (anti-PD1). }\end{array}$ & $p<0.05$ \\
\hline $\begin{array}{l}\text { Cell proliferation } \\
\text { (Ki67). }\end{array}$ & Same as above. & Same as above. & $\begin{array}{l}\text { IL-7 treatment increased the } \\
\text { percentage of Ki67 positive splenic } \\
\text { CD8+ T cells compared to an } \\
\text { alternative therapy (anti-PD1). }\end{array}$ & $p<0.05$ \\
\hline $\begin{array}{l}\text { Surface markers (LFA-1 } \\
\text { and VLA-4). }\end{array}$ & Same as above. & Same as above. & $\begin{array}{l}\text { IL-7 treatment increased the } \\
\text { percentage of positivity for VLA-4 } \\
\text { and LFA-1 compared to saline or } \\
\text { anti-PD-1 treated mice. }\end{array}$ & $p<0.05$ \\
\hline Activation (IFN- $\gamma$ ) & Same as above. & Same as above. & $\begin{array}{l}\text { IL-7 significantly increased the } \\
\text { percentage of CD8 T cells that were } \\
\text { positive for IFN- } \gamma,\end{array}$ & $p<0.05$ \\
\hline
\end{tabular}


Table 7: Results from Shindo et al. ${ }^{14}$

\begin{tabular}{|l|l|l|l|l|}
\hline Assessment & $\begin{array}{l}\text { Sample and } \\
\text { Grouping }\end{array}$ & Intervention & Outcome & p-value \\
\hline Overall survival. & $\begin{array}{l}\text { n=25 per group } \\
\text { (rhIL-7; saline). }\end{array}$ & $\begin{array}{l}\text { After sepsis induction } \\
\text { (CLP and P.aeruginosa } \\
\text { pneumonia), mice received } \\
2.5 \mu \text { of IL-7 for 6 days } \\
\text { consecutively. }\end{array}$ & $\begin{array}{l}\text { IL-7 treatment improves survival in } \\
\text { septic animals. }\end{array}$ & $p=0.006$ \\
\hline $\begin{array}{l}\text { Spleen and lung cell } \\
\text { count. }\end{array}$ & Same as above. & Same as above. & $\begin{array}{l}\text { IL-7 treatment increased the } \\
\text { absolute number of CD8+ T cells, } \\
\text { NKT cells, } \gamma \delta \text { T cells, ILC2 and } \\
\text { ILC3 in either the lung or spleen of } \\
\text { septic mice. }\end{array}$ & $p<0.01-0.05$ \\
\hline $\begin{array}{l}\text { Humoral markers } \\
\text { (IL-17, IL-22, IFN- } \gamma, \\
\text { and TNF- } \alpha \text { ). }\end{array}$ & Same as above. & Same as above. & $\begin{array}{l}\text { IL-7 treatment did not increase } \\
\text { the levels of IL-17, IL-22, IFN- } \gamma, \\
\text { and TNF- } \alpha \text { in septic mice fluids } \\
\text { (plasma; bronchoalveolar lavage; } \\
\text { lung and spleen homogenate). }\end{array}$ & - \\
\hline $\begin{array}{l}\text { Cytokine-producing } \\
\text { cell count (lung and } \\
\text { spleen). }\end{array}$ & Same as above. & Same as above. & $\begin{array}{l}\text { IL-7 treatment increased the } \\
\text { number of IL-17-, IL-22-, and } \\
\text { IFN- } \gamma-\text { producing CD8+ T cells; } \\
\text { TNF- } \alpha-\text { and IFN- } \gamma-\text { producing } \gamma \delta \\
\text { T, NKT and NK cells; and IL-17-, } \\
\text { TNF- } \alpha-\text { and IFN- } \gamma-\text { producing ILC } \\
\text { in septic mice lungs and spleen. }\end{array}$ & $p<0.001-0.05$ \\
\hline $\begin{array}{l}\text { Intracellular markers } \\
\text { (pp65 and pSTAT3). }\end{array}$ & Same as above. & Same as above. & $\begin{array}{l}\text { IL-7 treatment increased pp65 and } \\
\text { pSTAT3 protein levels in septic } \\
\text { mice lungs. }\end{array}$ & $p<0.05$ \\
\hline
\end{tabular}

Table 8: Results from Kulkarni et al. ${ }^{15}$

\begin{tabular}{|c|c|c|c|c|}
\hline Assessment & $\begin{array}{l}\text { Sample and } \\
\text { Grouping }\end{array}$ & Intervention & Outcome & p-value \\
\hline $\begin{array}{l}\text { Regulatory cell count } \\
\text { (IL-10+ B cells). }\end{array}$ & $\begin{array}{l}\mathrm{n}=6-10(1 \\
\text { week), 9-16 (1 } \\
\text { month), 7-16 (3.5 } \\
\text { months) per group } \\
\text { (sham; sepsis; } \\
\text { sepsis+IL7). }\end{array}$ & $\begin{array}{l}\text { Mice were treated with } 2.5 \\
\mu \mathrm{g} \text { of rhIL- } 7 \text { from day } 5 \text { to } \\
9 \text { after sepsis induction. IL- } \\
10+\text { B cells from the spleen } \\
\text { were analysed } 1 \text { week, } 1 \\
\text { month and } 3.5 \text { months after } \\
\text { sepsis induction. }\end{array}$ & $\begin{array}{l}\text { IL- } 7 \text { treatment increased the } \\
\text { count of IL-10+ B cells. IL- } 7 \\
\text { increases the total B cells. }\end{array}$ & $\begin{array}{l}p<0.05 \text { ( } 1 \text { week } \\
\text { and } 1 \text { month) } \\
p<0.01 \text { ( } 3.5 \\
\text { months). }\end{array}$ \\
\hline $\begin{array}{l}\text { Regulatory cell count } \\
\text { (Foxp3+CD4+ T cells } \\
\text { count). }\end{array}$ & $\begin{array}{l}\mathrm{n}=7-13(1 \text { week }) \\
9-16(1 \text { month }) \\
5-18 \text { (3.5 months). }\end{array}$ & Same as above. & $\begin{array}{l}\text { IL-7 treatment led to } \\
\text { a transient increase in } \\
\text { Foxp3+ CD4+ CD25+ Treg } \\
\text { population. }\end{array}$ & $p<0.05$ \\
\hline $\begin{array}{l}\text { Regulatory cell count } \\
\text { (Double negative } \\
\text { CD3+, CD4-, CD8- T } \\
\text { cells). }\end{array}$ & $\begin{array}{l}\mathrm{n}=7-13(1 \text { week }) \\
5-10(1 \text { month }) \\
3-6 \text { (3.5 months). }\end{array}$ & Same as above. & $\begin{array}{l}\text { IL-7 treatment led to a } \\
\text { sustained increase in CD3+, } \\
\text { CD4-, CD8- (DN) Treg } \\
\text { population. }\end{array}$ & $p<0.001$ \\
\hline $\begin{array}{l}\text { Regulatory cell count } \\
\text { (myeloid-derived } \\
\text { suppressor cells). }\end{array}$ & $\begin{array}{l}\mathrm{n}=6-9(1 \text { week }) \\
5-12(1 \text { month }) \\
8-20 \text { (3.5 months). }\end{array}$ & Same as above. & $\begin{array}{l}\text { IL- } 7 \text { treatment led to a } \\
\text { sustained increased MDSC } \\
\text { population. }\end{array}$ & $p<0.001$ \\
\hline $\begin{array}{l}\text { Cell proliferation } \\
\text { (CD4+ T cells under } \\
\text { MDSC) }\end{array}$ & $\begin{array}{l}\mathrm{n}=3-4 \text { (for all } \\
\text { groups). }\end{array}$ & Same as above. & $\begin{array}{l}\text { IL- } 7 \text { treatment led to a } \\
\text { were slightly, almost not } \\
\text { significantly, more resistant } \\
\text { to the effect of MDSCs. }\end{array}$ & - \\
\hline
\end{tabular}

\section{Human ex vivo Studies}

Human ex vivo studies were performed by blood sampling patients either 1-4 days after septic shock, or after 24-48 hours of cultures returning positive for multiple drug resistant bacteria. In regard to bias and certainty evaluation, in vitro studies had no septic control groups, but healthy or critical controls instead. There was no blinding.

\subsection{IL-7 increases intranuclear markers STAT5 and BCL2}

STAT5 and BCL2 are key intracellular effectors recruited by the activation of the IL-7. IL-7 was shown to 
reverse the diminished STAT5 phosphorylation and BCL2 expression in septic patients. ${ }^{16}$ The phosphorylation of the transcription factor STAT5 was recorded to be higher on effector rather than regulatory CD4 $\mathrm{T}$ cells of healthy patients treated with IL- $7^{17}$. Finally, it was also shown to be increased in the effector cells of survivors ${ }^{17}$.

\subsection{IL-7 improved IFN- $\gamma$ production}

IL-7, among other immunoadjuvants, was the most effective at increasing the number of IFN- $\gamma$ producing $\mathrm{T}$ cells, raising it by at least $20 \%$ in $62.5 \%$ (15 out of 24 ) of septic patients and in $81.2 \%$ (13 out of 16$)$ of critical, but not septic, patients ${ }^{19}$. Another study showed that the percentage of IFN- $\gamma$ producing CD8 T cells of septic patients incubated with IL-7 were no different from that of healthy controls ${ }^{16}$.

\subsection{IL-7 increases cell proliferation}

Table 9: Results from Venet et al. ${ }^{16}$
After TCR stimulation, IL-7 was able to significantly increase the proliferation count of mononuclear lymphocytes of septic patients, which included the selective expansion of CD4 and CD8 T cells in septic patients to levels similar to controls ${ }^{16}$.

\subsection{IL-7 restores $\mathrm{T}$ cell metabolic alteration in sepsis}

IL-7 treatment reversed metabolic abnormalities seen in CD4 T cells of septic patients. The activation of the mammalian target of rapamycin (mTOR), GLUT1 expression and glucose uptake were all raised in treated lymphocytes, whereas the change in AkT phosphorylation did not reach significance ${ }^{18}$.

\subsection{Individual result tables}

The individual results for each study are summarized in Tables 9 to 12 .

\begin{tabular}{|c|c|c|c|c|}
\hline Assessment & $\begin{array}{l}\text { Sample and } \\
\text { Grouping }\end{array}$ & Intervention & Outcome & p-value \\
\hline $\begin{array}{l}\text { Lymphocyte } \\
\text { proliferation. }\end{array}$ & $\begin{array}{l}\mathrm{n}=10 \text { per } \\
\text { group (septic } \\
\text { and healthy). }\end{array}$ & $\begin{array}{l}\text { Isolated mononuclear cells were } \\
\text { cultured for } 5 \text { days in the presence } \\
\text { or not of anti-CD2/CD3/CD28 Ab- } \\
\text { coated beads and rhIL-7 (100 ng/ } \\
\text { ml). }\end{array}$ & $\begin{array}{l}\text { Cell incubation with IL- } 7 \text { significantly } \\
\text { increased proliferative response in septic } \\
\text { shock patients. No significant effect on } \\
\text { healthy volunteers. }\end{array}$ & $p<0.05$ \\
\hline $\begin{array}{l}\text { Specific CD4+ } \\
\text { and CD8+ } \\
\text { lymphocyte } \\
\text { proliferation. }\end{array}$ & $\begin{array}{l}\mathrm{n}=7 \text { (septic } \\
\text { shock) and } \\
\mathrm{n}=4 \text { (healthy } \\
\text { volunteers). }\end{array}$ & $\begin{array}{l}\text { Mononuclear cells stained with } \\
\text { CFSE and cultured for } 5 \mathrm{~d} \text { in the } \\
\text { presence or not of anti-CD2/CD3/ } \\
\text { CD28 Ab-coated beads and rhIL-7 } \\
(100 \mathrm{ng} / \mathrm{ml}) \text {. }\end{array}$ & $\begin{array}{l}\mathrm{CD} 4+\text { and } \mathrm{CD} 8+\text { lymphocyte } \\
\text { proliferations are restored by IL- } 7 \text { in } \\
\text { septic shock patients. }\end{array}$ & $p<0.05$ \\
\hline $\begin{array}{l}\text { Activation } \\
(\text { IFN- } \gamma \text { ). }\end{array}$ & $\begin{array}{l}\mathrm{n}=12 \text { (septic } \\
\text { shock) } \\
\text { and } \mathrm{n}=10 \\
\text { (healthy } \\
\text { volunteers). }\end{array}$ & $\begin{array}{l}\text { Isolated mononuclear cells were } \\
\text { cultured for } 4 \mathrm{~h} \text { in the presence or } \\
\text { not of anti-CD } 2 / \mathrm{CD} 3 / \mathrm{CD} 28 \mathrm{Ab}- \\
\text { coated beads and rhIL-7 }(100 \mathrm{ng} / \mathrm{ml})\end{array}$ & $\begin{array}{l}\text { IFN- } \gamma \text { production by CD } 8+\mathrm{T} \\
\text { lymphocytes is restored by IL- } 7 \text { in septic } \\
\text { shock patients. }\end{array}$ & $p<0.01$ \\
\hline $\begin{array}{l}\text { Intracellular } \\
\text { markers and } \\
\text { apoptosis. }\end{array}$ & $\begin{array}{l}\mathrm{n}=10 \text { per } \\
\text { group (septic } \\
\text { and healthy). }\end{array}$ & $\begin{array}{l}\text { Mononuclear cells were cultured } \\
\text { overnight in the presence or not of } \\
\text { anti-CD } 2 / \mathrm{CD} 3 / \mathrm{CD} 28 \mathrm{Ab} \text {-coated } \\
\text { beads and } 15 \mathrm{~min} \text { in the presence or } \\
\text { not of rhIL- } 7(100 \mathrm{ng} / \mathrm{ml}) \text {. }\end{array}$ & $\begin{array}{l}\text { STAT5 phosphorylation and BCL2 } \\
\text { induction in T lymphocytes are restored } \\
\text { by IL-7 in septic shock patients. }\end{array}$ & $p<0.01$ \\
\hline
\end{tabular}

Table 10: Results from Demaret et al. ${ }^{17}$

\begin{tabular}{|l|l|l|l|l|}
\hline Assessment & $\begin{array}{l}\text { Sample and } \\
\text { Grouping }\end{array}$ & Intervention & Outcome & -value \\
\hline $\begin{array}{l}\text { Intracellular } \\
\text { markers (STAT5). } \\
\mathrm{n}=13 \text { (septic } \\
\text { patients) and } \\
\mathrm{n}=10 \text { (healthy } \\
\text { volunteers). }\end{array}$ & $\begin{array}{l}\text { CD4 + T cells were stimulated with } \\
\text { increasing concentrations of rhIL-7 } \\
\text { and then marked with anti-CD4, } \\
\text { anti-pSTAT5 and anti-FOXP3. }\end{array}$ & $\begin{array}{l}\text { The lowest concentrations of IL-7 } \\
(1 \mathrm{pg} / \mathrm{ml} \text { ) significantly increased } \\
\text { the phosphorylation of STAT5 on } \\
\text { Teffector lymphocytes in septic } \\
\text { patients (but not T regulatory). }\end{array}$ & $p<0.02$ \\
\hline $\begin{array}{l}\text { Intracellular } \\
\text { markers (STAT5). }\end{array}$ & $\begin{array}{l}\text { Same as } \\
\text { above. }\end{array}$ & Same as above. & $\begin{array}{l}\text { The lowest concentrations of IL-7 } \\
\text { (1 pg/ml) significantly increased the } \\
\text { phosphorylation of STAT5 of both T } \\
\text { effector and regulatory lymphocytes } \\
\text { in healthy controls. }\end{array}$ & $p<0.002$ \\
\hline
\end{tabular}


Table 11: Results from Venet et al. ${ }^{18}$

\begin{tabular}{|c|c|c|c|c|}
\hline Assessment & $\begin{array}{l}\text { Sample and } \\
\text { Grouping }\end{array}$ & Intervention & Outcome & p-value \\
\hline $\begin{array}{l}\text { Intracellular } \\
\text { markers (mTOR). }\end{array}$ & $\begin{array}{l}\mathrm{n}=6-19 \text { (septic } \\
\text { patients). }\end{array}$ & $\begin{array}{l}\text { Peripheral blood mononuclear cell } \\
\text { were isolated and allowed to rest } \\
\text { for } 1 \mathrm{~h} \text { and then were stimulated } \\
\text { with anti-CD2-CD3-CD28 Ab- } \\
\text { coated beads and PHA ( } 4 \mathrm{mg} / \mathrm{ml}) \\
\text { for } 15 \mathrm{~min} \text { or with anti-CD2-CD3- } \\
\mathrm{CD} 28 \mathrm{Ab}-\text { coated beads and rhIL-7 } \\
(100 \mathrm{ng} / \mathrm{ml}) \text { and } / \text { or with } \\
\text { rapamycin }(10 \mathrm{ng} / \mathrm{ml}) \text { for } 72 \mathrm{~h} \text {. }\end{array}$ & $\begin{array}{l}\text { IL- } 7 \text { treatment promoted mTOR } \\
\text { activation (average increase }=123 \% \\
\text { versus untreated cells) in septic T } \\
\text { cells. }\end{array}$ & $p<0.005$ \\
\hline $\begin{array}{l}\text { Intracellular } \\
\text { markers } \\
\text { (GLUT1). }\end{array}$ & $\begin{array}{l}\mathrm{n}=8-30 \text { (septic } \\
\text { patients). }\end{array}$ & Same as above. & $\begin{array}{l}\text { IL-7 treatment promoted significant } \\
\text { increase in intracellular GLUT1 } \\
\text { expression in septic T cells. }\end{array}$ & $p<0.005$ \\
\hline $\begin{array}{l}\text { Glucose } \\
\text { metabolism. }\end{array}$ & $\begin{array}{l}\mathrm{n}=8-31 \text { (septic } \\
\text { patients). }\end{array}$ & Same as above. & $\begin{array}{l}\text { IL- } 7 \text { treatment increased glucose } \\
\text { entry into septic T cells. }\end{array}$ & $p<0.005$ \\
\hline Proliferation. & $\begin{array}{l}\mathrm{n}=8-30 \text { (septic } \\
\text { patients). }\end{array}$ & Same as above. & $\begin{array}{l}\text { IL-7 treatment improved } \\
\text { proliferation }(11 \pm 6 \% \text { versus } 23 \pm 7 \% \\
\text { proliferating CD4 }+ \text { cells }) .\end{array}$ & $p<0.005$ \\
\hline
\end{tabular}

Table 12: Results from Thampy et al. ${ }^{19}$

\begin{tabular}{|c|c|c|c|c|}
\hline Assessment & $\begin{array}{l}\text { Sample and } \\
\text { Grouping }\end{array}$ & Intervention & Outcome & p-value \\
\hline IFN- $\gamma$ secretion. & $\begin{array}{l}\mathrm{n}=24 \text { (septic } \\
\text { patients). }\end{array}$ & $\begin{array}{l}\text { Peripheral blood mononuclear cells } \\
\text { were stimulated overnight with } \\
\text { RPMI } 1640 \text { media supplemented } \\
\text { with } \\
\text { human AB serum containing anti- } \\
\text { CD3/anti-CD28, and rhIL-7 ( } 50 \mathrm{ng} / \\
\text { ml). }\end{array}$ & $\begin{array}{l}15 \text { of } 24 \text { septic patients }(62.5 \%) \\
\text { responded to IL- } 7 \text { treatment. } \\
\text { Response was determined as the } \\
\text { increase in the number of cells } \\
\text { positive for IFN- } \gamma \text { immunostaining of } \\
\text { at least } 20 \% \text { compared to the control. }\end{array}$ & - \\
\hline
\end{tabular}

\section{Clinical Trial}

The IRIS-7 clinical trial, registered under NCT02640807 and NCT02797431, is the first trial to date to administer IL-7 to septic patients. It is also the first clinical trial to target adaptive immunity, in contrast to previous clinical immunoadjuvant trials focused on innate immunity, such as those of IFN- $\gamma$, G-CSF and CG-CSF, or the other several past trials focusing on immunosuppression ${ }^{9}$.

The chosen initial dosage was $10 \mu \mathrm{g} / \mathrm{kg}$ of CYT107 twice a week for the first week on 17 septic patients. Afterwards, two different dosing regimens were established: one group $(\mathrm{n}=8)$ was treated with $10 \mu \mathrm{g} / \mathrm{kg}$ CYT107 once a week (low frequency), while the second group $(\mathrm{n}=9)$ was treated with CYT10710 $\mu \mathrm{g} / \mathrm{kg}$ twice a week (high frequency). The total therapy time for both groups was 4 weeks.

As for bias and certainty assessment, the clinical trial was randomized, double-blind and placebo-controlled, with full description of method, selection, dropout criteria and results.

\subsection{IL-7 improved lymphocyte cell count and proliferation}

On average, both high and low-frequency groups exhibited a 3.5 to 4.5 fold increase in absolute lymphocyte counts on the 8th day of therapy (three doses had been administered). Moreover, the total cell expansion lasted for 2-4 weeks after the discontinuation of treatment. Specifically, CD4 T cells were four times as numerous as before the beginning of the therapy in both groups, and CD8 cell counts were higher in the high-frequency group, but not in the low one. The low-frequency group also exhibited a significant, transient, decrease in circulating CD8 T cells, which was coincident with augmented homing molecules expression ${ }^{9}$.

As for proliferation, as marked by Ki67 expression, IL-7 treatment failed to show significant differences after adjustment for baseline, although CD4 and CD8 T cells positive for KI67 did exhibit a significant increase in a few selected days ${ }^{9}$.

\subsection{IL-7 regulated surface molecules}

IL-7 receptor $\alpha$, known to be downregulated soon after IL-7 administration, had decreased in CD4 and CD8 T cell expression in patients treated with both low- and highfrequency treatment regimens versus placebo on day $4^{9}$.

As for lymphocyte activation markers, IL-7 did improve CD38 expression on CD4 T cells, but failed to 
do so on CD8 T cells. Other markers, such as HLA-DR, showed significant change only on a few selected days, and there was no sufficient evidence of PD-1 expression difference ${ }^{9}$.

\subsection{Result table}

The results from the clinical trial are summarized in Table 13

Table 13: Results from Francois et al. ${ }^{9}$

\begin{tabular}{|c|c|c|c|c|}
\hline Assessment & $\begin{array}{l}\text { Sample and } \\
\text { Grouping }\end{array}$ & Intervention & Outcome & p-value \\
\hline Overall survival. & $\begin{array}{l}\mathrm{n}=10 \text { (placebo). } \\
\mathrm{n}=8 \text { (low } \\
\text { frequency) } \\
\text { CYT107). } \mathrm{n}=9 \\
\text { (placebo). }\end{array}$ & $\begin{array}{l}\text { Patients received } 10 \mu \mathrm{g} / \mathrm{kg} \text { IL- } 7 \text { twice } \\
\text { a week for the first week. Afterwards, } \\
\text { they received } 10 \mu \mathrm{g} / \mathrm{kg} \text { IL- } 7 \text { either } \\
\text { once (low frequency) or twice (high } \\
\text { frequency) a week. Therapy was } \\
\text { continued for a total of } 4 \text { weeks. }\end{array}$ & $\begin{array}{l}15 \text { of } 24 \text { septic patients }(62.5 \%) \\
\text { responded to IL- } 7 \text { treatment. } \\
\text { Response was determined as the } \\
\text { increase in the number of cells } \\
\text { positive for IFN- } \gamma \text { immunostaining } \\
\text { of at least } 20 \% \text { compared to } \\
\text { the control. }\end{array}$ & - \\
\hline Cell count. & Same as above. & Same as above. & $\begin{array}{l}\text { IL-7 treatment significantly } \\
\text { increased the absolute lymphocyte } \\
\text { count in both low- and high- } \\
\text { frequency group patients. } \\
\text { This increase in circulating } \\
\text { lymphocytes persisted for at least } \\
2-4 \text { weeks. }\end{array}$ & $p=0.004$ \\
\hline $\begin{array}{l}\text { Cell count (CD4+ } \\
\text { and CD8+ T cells) }\end{array}$ & Same as above. & Same as above. & $\begin{array}{l}\text { IL-7 treatment increased the CD } 4 \\
+ \text { T cell count in both low- and } \\
\text { high-frequency group patients. It } \\
\text { also increased the CD } 8+T \text { cell } \\
\text { count in the high-frequency group } \\
\text { patients. }\end{array}$ & $\begin{array}{l}p=0.021- \\
0.030\end{array}$ \\
\hline $\begin{array}{l}\text { Cell count (CD8+ } \\
\text { T cells) }\end{array}$ & Same as above. & Same as above. & $\begin{array}{l}\text { IL- } 7 \text { provoked a transient } \\
\text { reduction in CD } 8+T \text { cell count on } \\
\text { day } 4 \text { compared to controls. The } \\
\text { result was only significant for the } \\
\text { low frequency group. }\end{array}$ & $p=0.009$ \\
\hline $\begin{array}{l}\text { Innate immunity } \\
\text { (neutrophil } \\
\text { count). }\end{array}$ & Same as above. & Same as above. & $\begin{array}{l}\text { IL-7 treatment increased the } \\
\text { absolute neutrophil count. The } \\
\text { result was only significant for the } \\
\text { high frequency group. }\end{array}$ & $p<0.01$ \\
\hline $\begin{array}{l}\text { Proliferation } \\
\text { (Ki67). }\end{array}$ & Same as above. & Same as above. & $\begin{array}{l}\text { IL- } 7 \text { treatment increased the } \\
\text { percentage of Ki67-positive } \\
\text { CD } 4+\text { and CD } 8+\text { T cells in both } \\
\text { treatment groups. }\end{array}$ & $\begin{array}{l}p<0.01- \\
0.05\end{array}$ \\
\hline $\begin{array}{l}\text { Surface marker } \\
\text { (IL-7R } \alpha)\end{array}$ & Same as above. & Same as above. & $\begin{array}{l}\text { IL-7 treatment decreased IL-7 } \\
\text { receptor } \alpha \text { (CD127) expression in } \\
\text { CD4+ and } \\
\text { CD8+ T cells in both treatment } \\
\text { groups. }\end{array}$ & $\begin{array}{l}p<0.011- \\
0.001\end{array}$ \\
\hline $\begin{array}{l}\text { Activation (CD38 } \\
\text { and HLA-DR and } \\
\text { PD-1). }\end{array}$ & Same as above. & Same as above. & $\begin{array}{l}\text { IL-7 treatment significantly } \\
\text { increased CD } 38 \text { expression in } \\
\text { CD4+ T cells. The result was only } \\
\text { significant for the low frequency } \\
\text { group. }\end{array}$ & $p=0.004$ \\
\hline
\end{tabular}

\section{DISCUSSION}

In the light of all of the reviewed articles, IL-7 treatment seems to be a promising option to the still unaccounted burden of sepsis. In the past decade, animal and ex vivo studies have progressively worked on the various effects of IL-7 in restoring immune function. The IRIS-7 trial, although still insufficient as a source of evidence for the efficacy of the treatment, also demonstrated some of the previous findings on actual patients. Taking into account all the compiled experimental data, IL-7 treatment seems to have three major features that may account for its potential to improve survival.

The first would be IL-7 effect on improving leukocyte cell number counts, whose depletion is a hallmark of sepsis and it is tied to poor outcome ${ }^{20}$. The cytokine seems to increase lymphocyte count by two major pathways. One would be through increased proliferation, which was determined by several studies using enhanced Ki67 expression as a maker ${ }^{10,12-14}$, or $3 \mathrm{H}$-thymidine ${ }^{16}$. Another positive effect would be its antiapoptotic effect, evaluated through either the upregulation of antiapoptotic 
protein $\mathrm{Bcl}-2(10,11)$ or the downregulation of the proapoptotic BH3 molecules such as Bim, PUMA and $\mathrm{BMF}^{10}$. Overall, a general finding of the studies was that $\mathrm{CD}$ $8 \mathrm{~T}$ cell numbers seemed to respond with greater potency to IL-7 than CD $4 \mathrm{~T}$ cells.

The second proposed major impact of the cytokine on survival is related to its potential to improve lymphocyte function. Several studies evaluated such activation, pointing towards enhanced production of IFN- $\gamma$ and other cytokines, upregulated expression of receptors like CD8 and cell adhesion molecules like LFA-1 and VLA-4, less deranged cell metabolism and enhanced activation of key transcription factors.

IFN- $\gamma$ is a cytokine implicated in phagocyte activation, improving their own cytokine production, phagocytosis and antigen-presentation, which play an essential role in fighting opportunistic nosocomial agents such as Candida ${ }^{12}$. IFN- $\gamma$ also acts to promote other downstream effects in both adaptive and innate immune cells, such as the recruitment of $\gamma \delta$ T cells and neutrophils mediated through the upregulated interferon gamma inducible protein 10 (IP-10) ${ }^{11}$. Finally, IL-7 therapy also had an impact on other cytokines, as it increased the number of cells producing IL-17 and TNF- $\alpha$. This role of IL-7 treatment on multiple cytokines concentrations is probably related to its activation of $\mathrm{CD} 4+$ cells, which guide both adaptive and innate immune response $\mathrm{e}^{11}$.

Another promising marker for lymphocyte activation induced by IL-7 therapy was the reversal of sepsis caused metabolic derangements. As lymphocytes are activated, their metabolism changes from a catabolic, $\beta$ oxidation focused metabolism, to an anabolic, glycolytic one (Warburg effect). Sepsis seems to interfere with this process, reverting lymphocytes from a fatty oxidation pattern characteristic of anergic cells. IL-7 treatment, however, through the activation of mTOR, was able to make the cells regain the effector, proliferative, glycolytic profile $^{18}$.

Finally, NF-kB signalling, which promotes cytokine production, and STAT3, a downstream factor of cytokine signalling, were shown to be increased by IL- 7 treatment ${ }^{14}$.

Moving on from activation results, a third advantage of IL-7, especially against other pro-inflammatory cytokines, is the fact that IL-7 treatment does not lead to an exacerbated immune response. IL-7 seems to play a role in regular lymphocyte homeostasis, as it is a limited resource continually produced by stromal cells. Lymphocytes normally compete for the cytokine, and receptor activation leads to IL-7R $\alpha$ downregulation and increases the available pool. Similarly, in cases of lymphopenia, the concentration of IL-7 rises, which promotes the restoration of lymphocyte population ${ }^{8}$. IL-7 also promotes co-stimulatory effects on naive $\mathrm{T}$ cells, and resting memory $\mathrm{T}$ cells reexpress the receptor for it. In contrast to IL-2, IL-7 supports the lymphocyte population not exposed to signs of activation. For instance, IL-7R $\alpha$ is expressed in recent thymic emigrants (RTEs), inducing proliferation in the absence of TCR signalling. Finally, the internalization IL-7R $\alpha$ after ligation may be responsible for the lack of an overstimulated inflammatory response in most experiments, except for a grade 2-3 rash observed in 4 of 17 patients in the clinical trial ${ }^{9}$.

The combination of several immunostimulant effects, reverting key sepsis abnormalities, tied to a controlled immune response, sets IL-7 apart from most previous anti-inflammatory drugs. In addition, IL-7 has a different profile from some of the pro-inflammatory interventions, such as IL-2, which may induce symptoms such as fever and capillary leak syndrome ${ }^{10}$. Nevertheless, IL-7 still needs further investigation on its role against sepsis, as the retrieved studies had a number of limitations.

A major limitation of the studies is related to the complexity and dynamicity of the disease course, as a single time point was usually selected ${ }^{19}$. Sepsis per se is a complex disease, and generalizability may always prove to be challenging. For instance, in one study later administration of IL-7 (5-9 days after CLP) was shown to increase immunoregulatory cell population ${ }^{15}$.

As for the clinical trial, a possible limitation was the lymphopenia inclusion criterion, defined as an absolute lymphocyte count of 900 lymphocytes/ $\mu 1$ or lower. Lymphopenia is tied to a poor prognosis in sepsis ${ }^{20}$, and it seems to be a central factor in the pathophysiology of the disease in several animal studies'. Even so, it should be advisable to evaluate the impact of IL-7 treatment in septic but no lymphopenic patients, or even those that show cell dysfunction rather than the low absolute count.

Another limitation is that the clinical trial did not evaluate tissue lymphocyte count, but only circulating numbers. Although IL-7 treatment was shown to increase the number of lymphocytes in spleen and diffuse lymphoid tissues in $\mathrm{HIV}^{21}$ and cancer ${ }^{22}$ clinical trials, it may not work in the same way in sepsis, considering the rather complex effect of the disease in multiple immune functions, as for instance leukocyte trafficking. Notwithstanding, animal models show the same initial decrease in circulating levels, followed by a rebound, after IL-7 treatment in septic patients, suggesting a homing response 9 .

High heterogeneity of samples, including comorbidities, site and type of infection and evolution of clinical status, was also a relevant factor in the trial. Some studies resorted to nonseptic, but critically-ill, controls, who could be highly different among each other for altered immune function ${ }^{19}$. Some ex vivo studies also did not match the age of patients and controls, even if the immune parameters analysed seemed to not be modified by $\mathrm{it}^{18}$. Specific sepsis courses may also have been responsible for unexpected results in the trial, such as better responses from low-frequency patients, or high count of neutrophils in high-frequency ones? 
To minimize the highly variable presentation and timing of sepsis, there is great interest in expanding markers and testing methods. For instance, immunoassay tests for low IFN- $\gamma$ or other impaired T cells function markers may be used to identify possible patients for immunotherapy, including IL-7. Considering ex vivo tests limitations, even patients whose cells are unresponsive may benefit from treatment with IL-7, especially considering its targeting of multiple immune functions ${ }^{19}$. At least one ex vivo study showed different results of IL-7 treatment in surviving and non surviving patients, according to key flow cytometry results, which could anticipate responses to cytokine therapy ${ }^{17}$.

Another constraint on evaluation of the effects of IL-7 was the restricted follow-up after administration. IL-7 therapy has a still unknown impact on long term immune regulation. IL-7 seems to increase the number of regulatory $\mathrm{T}$ cells, regulatory $\mathrm{IL}-10+\mathrm{B}$ cells and MDSC, promoting long-term effects on still unknown impact on sepsis survival ${ }^{19}$. Nevertheless, an ex vivo study showed a preferred activation of STAT5 of effector T cells rather than regulatory ones ${ }^{17}$.

All the listed limitations open possibilities for further intervention and research. Thus, as for recommendation, given the complexity of sepsis, not only a larger trial is in order to assess the effectiveness of IL-7 as a treatment, but also one capable of addressing the heterogeneity of patients. Particularly, future trials should consider the timing of intervention, the biomarker profile, especially in regard to cytokine levels and cell counts, and the number of comorbidities of patients when evaluating the eligibility, and advisability, of IL-7 treatment.

Another recommendation, in regard to future animal studies, could be a greater focus on the pathways downstream to IL-7 that could be responsible for the improved survival. Even if the cytokine has been shown to improve lymphocyte numbers and activation, mechanisms posterior to such effect are still partially unaccounted, and could answer questions raised in new clinical trials design. Another point of major interest for animal studies are the long to mid-term effects of IL-7 treatment, especially concerning its effect on regulatory immune cells.

\section{CONCLUSION}

Sepsis is but one of the several diseases currently under study as a promising target for IL-7 treatment. However, in comparison to the other disorders, sepsis still lags behind when it comes to immunotherapy, in no small part for its complicated clinical course. Nevertheless, immunostimulation shows great, if initially prospects, for long-term survival of sepsis. After reviewing the current literature, from early experiments on animal survival to ex vivo studies on human cells to the recent clinical trial, we can conclude IL-7 is among one of these new potential immunomodulatory drugs. The actual efficacy of IL-7 on sepsis survival, however, still requires a larger, randomized, double blind trial, which should soon be started.

Additional Information: The authors received no financial support for the current review. The authors declare no competing interests. The public availability status of the presented data is unknown.

Authors' participation: Prof. Dr. Francisco Garcia Soriano was the project advisor and supervisor. All medical students (Filipe Oto Cunha de Moraes, Guilherme Tetsuo Yokoy Numakura and Larissa Tami Hokama) participated in all phases of the article, including overall design and purpose, study selection, data analysis and manuscript review.

\section{REFERENCES}

1. Singer M, Deutschman CS, Seymour CW, Shankar-Hari M, Annane D, Bauer M, et al. The Third International Consensus Definitions for Sepsis and Septic Shock (Sepsis-3). JAMA. 2016;315(8):801-10. doi:10.1001/ jama.2016.0287.

2. Delano MJ, Ward PA. Sepsis-induced immune dysfunction: can immune therapies reduce mortality? J Clin Invest. 2016;126(1):23-31. doi: 10.1172/JCI82224.

3. Patil NK, Bohannon JK, Sherwood ER. Immunotherapy: a promising approach to reverse sepsis-induced immunosuppression. Pharmacol Res. 2016;111:688-702. doi: 10.1016/j.phrs.2016.07.019.

4. Tang BM, Huang SJ, McLean AS. Genome-wide transcription profiling of human sepsis: a systematic review. Crit Care. 2010;14(6):R237. doi: 10.1186/cc9392.

5. Marshall JC. Why have clinical trials in sepsis failed? Trends Mol Med. 2014;20(4):195-203. doi: 10.1016/j. molmed.2014.01.007.
6. Hotchkiss RS, Monneret G, Payen D. Sepsis-induced immunosuppression: from cellular dysfunctions to immunotherapy. Nat Rev Immunol. 2013;13(12):862-74. doi: $10.1038 /$ nri3552.

7. Boomer JS, Green JM, Hotchkiss RS. The changing immune system in sepsis: is individualized immuno-modulatory therapy the answer? Virulence. 2014;5(1):45-56. doi: $10.4161 /$ viru.26516.

8. Mackall CL, Fry TJ, Gress RE. Harnessing the biology of IL-7 for therapeutic application. Nat Rev Immunol. 2011;11(5):330-42. doi: 10.1038/nri2970.

9. Francois B, Jeannet R, Daix T, Walton AH, Shotwell MS, Unsinger J, et al. Interleukin-7 restores lymphocytes in septic shock: the IRIS-7 randomized clinical trial. JCI Insight. 2018;3(5). doi: 10.1172/jci.insight.98960.

10. Unsinger J, McGlynn M, Kasten KR, Hoekzema AS, Watanabe E, Muenzer JT, et al. IL-7 promotes T cell viability, trafficking, and functionality and improves survival in sepsis. J Immunol. 2010;184(7):3768-79. doi: 10.4049/jimmunol.0903151. 
11. Kasten KR, Prakash PS, Unsinger J, Goetzman HS, England LG, Cave CM, et al. Interleukin-7 (IL-7) treatment accelerates neutrophil recruitment through gamma delta T-cell IL-17 production in a murine model of sepsis. Infect Immun. 2010;78(11):4714-22. doi: 10.1128/IAI.00456-10.

12. Unsinger J, Burnham CA, McDonough J, Morre M, Prakash PS, Caldwell CC, et al. Interleukin-7 ameliorates immune dysfunction and improves survival in a 2-hit model of fungal sepsis. J Infect Dis. 2012;206(4):606-16. doi: 10.1093/ infdis/jis 383 .

13. Shindo Y, Unsinger J, Burnham CA, Green JM, Hotchkiss RS. Interleukin-7 and anti-programmed cell death 1 antibody have differing effects to reverse sepsis-induced immunosuppression. Shock. 2015;43(4):334-43. doi: 10.1097/SHK.0000000000000317.

14. Shindo Y, Fuchs AG, Davis CG, Eitas T, Unsinger $\mathrm{J}$, Burnham CD, et al. Interleukin 7 immunotherapy improves host immunity and survival in a two-hit model of Pseudomonas aeruginosa pneumonia. J Leukoc Biol. 2017;101(2):543-54. doi: 10.1189/jlb.4A1215-581R.

15. Kulkarni U, Herrmenau C, Win SJ, Bauer M, Kamradt T. IL-7 treatment augments and prolongs sepsis-induced expansion of IL-10-producing B lymphocytes and myeloidderived suppressor cells. PLoS One. 2018;13(2):e0192304. doi: 10.1371/journal.pone.0192304.

16. Venet F, Foray AP, Villars-Mechin A, Malcus C, PoitevinLater F, Lepape A, et al. IL-7 restores lymphocyte functions in septic patients. J Immunol. 2012;189(10):5073-81. doi: 10.1172/jci.insight. 98960 .

17. Demaret J, Dupont G, Venet F, Friggeri A, Lepape A, Rimmele T, et al. STAT5 phosphorylation in T cell subsets from septic patients in response to recombinant human interleukin-7: a pilot study. J Leukoc Biol. 2015;97(4):7916. doi: 10.1189/jlb.5AB1114-545R.

18. Venet F, Demaret J, Blaise BJ, Rouget C, Girardot T, Idealisoa E, et al. IL-7 Restores T Lymphocyte Immunometabolic Failure in Septic Shock Patients through mTOR Activation. J Immunol. 2017;199(5):1606-15. doi: 10.4049/jimmunol.1700127.

19. Thampy LK, Remy KE, Walton AH, Hong Z, Liu K, Liu R, et al. Restoration of $\mathrm{T}$ Cell function in multi-drug resistant bacterial sepsis after interleukin-7, anti-PD-L1, and OX40 administration. PLoS One. 2018;13(6):e0199497. doi: 10.1371/journal.pone.0199497.

20. Drewry AM, Samra N, Skrupky LP, Fuller BM, Compton SM, Hotchkiss RS. Persistent lymphopenia after diagnosis of sepsis predicts mortality. Shock. 2014;42(5):383-91. doi: 10.1097/SHK.0000000000000234.

21. Sereti I, Estes JD, Thompson WL, Morcock DR, Fischl MA, Croughs T, et al. Decreases in colonic and systemic inflammation in chronic HIV infection after IL-7 administration. PLoS Pathog. 2014;10(1):e1003890. doi: 10.1371/journal.ppat.1003890

22. Sportès C, Hakim FT, Memon SA, Zhang H, Chua KS, Brown MR, et al. Administration of rhIL-7 in humans increases in vivo TCR repertoire diversity by preferential expansion of naive T cell subsets. J Exp Med. 2008;205(7):1701-14. doi: 10.1084/jem.20071681.

Submeted: 2019, June 23 Accepted: 2021, June 17 